\title{
Antimicrobial activities of three seaweeds extract against some human viral and bacterial pathogens
}

\author{
Jelan MOFEED ${ }^{1,2, *}$; Mohamed DEYAB ${ }^{3}$; Abdelnaser MOHAMED ${ }^{3}$; Mahmoud MOUSTAFA ${ }^{4,5}$; SAlly NEGM ${ }^{6,7}$; \\ EMAD EL-BILAWY ${ }^{1}$ \\ ${ }^{1}$ Faculty of Science, King Salman International University, Sinai, Egypt \\ ${ }^{2}$ Faculty of Fish Resources, Suez University, Suez, Egypt \\ ${ }^{3}$ Faculty of Science, Damietta University, Damietta, Egypt \\ ${ }^{4}$ Department of Biology, College of Science, King Khalid University, Abha, 9004, Saudi Arabia \\ ${ }^{5}$ Department of Botany and Microbiology, Faculty of Science, South Valley University, Qena, Egypt \\ ${ }^{6}$ Life Sciences Department, Faculty of Science and Art, King Khalid University, Mahayel Aseer 61421, Saudi Arabia \\ ${ }^{7}$ Unit of Food Bacteriology, Central Laboratory of Food Hygiene, Ministry of Health, Sharkia, 44516, Egypt
}

Key words: Seaweeds, Antimicrobial, Antibacterial, Cytotoxicity, Antiviral

\begin{abstract}
Microbial infections cause complicated health influences along with bad economic impacts. In the present investigation, three dominant seaweeds namely, Amphiroa anceps, Corallina officinalis and Sargassum filipendula were collected from different Egyptian sites at the Red Sea and Mediterranean Sea during autumn 2019. Organic extracts of the three algae were screened for their antibacterial activity against three pathogenic bacteria Salmonella typhiimurium, Staphylococcus aureus and Escherichia coli, in addition to in vitro antiviral activity against Rotavirus (RV), and Coxsackie virus B3 (CVB3) that cause severe diseases in human. Organic extract of A. anceps, C. officinalis and S. filipendula inhibit E. coli cells by $57.1 \%, 85.7 \%$, and $91.4 \%$, respectively. The highest level of concentration of the C. officinalis extract $(100 \mu \mathrm{g} / \mathrm{mL})$ inhibits $100 \%$ of Staphylococcus aureus cells followed by S. filipendula and A. anceps extract which inhibit $82.5 \%$ and $75 \%$ of $S$. aureus. Similarly, the highest concentration of C. officinalis extract inhibits S. typhiimurium by $80 \%$. The extract of $A$. anceps exhibited a high antiviral effect against RV infection with TI $=22$ and virus titers lessened by $2.75 \log \mathrm{TCID}_{50}$ followed by extractions of $C$. officinalis with $\mathrm{TI}=18.3$ and virus titers reduced by $2.5 \log \mathrm{TCID}_{50}$. Against CVB3 infection, the extract of $A$. anceps causes the highest antiviral activity with TI $=15$ and reduce the viral titers by $2.5 \log \mathrm{TCID}_{50}$, followed by extractions of $C$. officinalis with $\mathrm{TI}=8.8$ and inhibition of virus titers by $1.75 \log \mathrm{TCID}_{50}$. Extract of S. filipendula displayed the lowest antiviral effects against RV and CVB3 infection with $\mathrm{TI}=2.4$ and 1.4, respectively. The obtained results clarified that the extract of three marine seaweeds maintains a potent antimicrobial activity, making them a future promising source of new antimicrobial drugs.
\end{abstract}

\section{Introduction}

Seaweeds, (macroalgae) are a large autotrophic diversified group (Fakayode et al., 2020). They can inhabit the splash zone in the seashore and down for about $30 \mathrm{~m}$ depth in the sea where they can obtain enough light for photosynthesis (Mine, 2008). Seaweeds have the capability to produce many unique chemical compounds that displayed many biological activities including antibiotics, antiviral, laxatives, anticoagulants, and anti-ulcer (El-Baroty et al., 2007; Schwartsmann et al., 2001).

*Address correspondence to: Jelan Mofeed, jelan.mofeed@ksiu.edu.eg Received: 27 January 2021; Accepted: 07 May 2021
Marine macroalgae produce a vast number of multifunction natural secondary metabolites, this is a consequence of continuous exposure to numerous abiotic along with biotic pressures, which enhance organisms to produce such metabolites (Al-Fadhli et al., 2006; Aslam et al., 2020).

Some seaweeds produce a number of interesting chemicals such as halogenated terpenoids which possess antibiotic effect, some red algae are famous for the sulfated polysaccharides like carrageenan and fucoidan which have antiviral and anticancer activities against many human viruses and cancer cells (Smit, 2004). Some seaweed fibers like alginate and laminarin have hypercholesteremic and hypolipidemic effects (Nishide and Uchida, 2003). Oxylipins is a metabolic product of polyunsaturated fatty acids 
(PUFAs) produced by many macroalgae and well known for their anti-inflammatory effect (Brito et al., 2016).

Besides, seaweeds are extensively used in the biosynthesis of nanoparticles using green chemistry technology. Many macroalgae are capable of the efficient bioproduction of nanoparticles with different sizes, shapes, and morphology which are used in different applications including pharmaceutical application especially antimicrobial activity in addition to removal of pollutants (Rezazadeh et al., 2020; Khalafi et al., 2019).

Despite the considerable benefits that bacteria provide in our life, there are some infectious species which counted as less than hundreds and can cause diseases in human, animals, and plants (McFall-Ngai, 2007).

Pathogenic bacteria cause a huge number of global health threats that may be fatal for humans including for instance pneumonia, typhoid fever, diphtheria, tetanus, syphilis, and leprosy (Kim et al., 2020). Staphylococcus aureus is a pathogen responsible for several diseases, including skin infections, toxic shock syndrome, and septic shock. Similarly, Escherichia coli and Salmonella typhimurium are the main causative agents of fatal diseases including uremia, hepatic failure, acute respiratory distress syndrome for E. coli, and typhoid fever for S. typhimurium (Mofeed et al., 2019). In the same line, the human viruses are very small obligate intracellular parasites that differ widely from other microorganisms and cause a number of fatal diseases to humans (Deyab et al., 2020). Coxsackie viruses B, is a prominent member of the (Picornaviridae family) could cause many chronic human diseases, such as cardiomyopathy, exanthema fever, neurological disorders, pancreatitis and severe neonatal diseases (Shaheen et al., 2017).

In the same context, Rotavirus (RV) is an eminent member that belongs to the family of Reoviridae and is regarded as the major reason for infants' diarrhea on a global scale, particularly in developing countries (Yeom et al., 2019). Rotavirus infection regarded to cause 450,000 deaths from 111 million incidences of infantile gastroenteritis annually (World Health Organization, 2013). In a world that suffers from the waning capabilities of antibiotics and the absence of effective antiviral drugs, there is a great need for effective, cheap, and safe alternatives. As a result of that, this work aimed at determining the antimicrobial activities of three marine macroalgae extracts including both the antibacterial activity against $S$. aureus, E. coli and $S$. typhimurium and the in vitro antiviral activity against both RV and CVB3 infections.

\section{Materials and Methods}

\section{Sampling sites}

Seaweed's biomasses were collected from two sites in the Mediterranean Sea, the first at Abu-Qir approximately 20 kilometers east of Alexandria lying longitude between $30^{\circ} 4^{\prime} \mathrm{E}$ and $30^{\circ} 20^{\prime} \mathrm{E}$, and latitude between $31^{\circ} 16^{\prime} \mathrm{N}$ and $31^{\circ} 28^{\prime} \mathrm{N}$, the second at Ras-Elbar City which is bordered by the Damietta Nile branch (N31 $30^{\prime} 45^{\prime \prime}$ E $\left.31^{\circ} 49^{\prime} 32^{\prime \prime}\right)$. Only one alga was collected from a site at Hurghada city in the Red Sea Governorate of Egypt, stretches for about $36 \mathrm{~km}$ (22 miles) along the seashore (N 27 $15^{\prime} 28^{\prime \prime}$ E $33^{\circ} 48^{\prime} 42^{\prime \prime}$ ).

\section{Collection of algal biomasses}

Three commonly flourished seaweed species were handpicked during the mid-autumn at a depth of $0.2 \mathrm{~m}$ or less from the rocking of Eastern Harbor water, Amphiroa anceps collected from Abo-Qir-Alexandria, Corallina officinalis from RasElbar-Damietta, and Sargassum filipendula was collected from the seashore of Hurghada-Red Sea, Egypt. The size of the collected living algal biomass samples (fresh weight) followed strictly the rules of the Egyptian Environmental Affairs Agency (EEAA) assigned for bio-conservation of the protected areas. Samples were collected along the intertidal zone using five quadrants $(1 \mathrm{~mm})$ according to Londo-scale (Londo, 1984).

\section{Preparation of dry biomass}

The algae samples were firstly rinsed several times with saline water and finally with distilled water to remove epiphytes and sediments, then identified to species levels (Brodie et al., 2016; de Clerck and Coppejans, 1996). Seaweeds were dried in shadow, cut into small pieces, macerated, and preserved in a well-closed dark amber-colored container.

\section{Biochemical component of algae}

Biochemical analysis was carried out to assess total protein, lipid, and carbohydrate content (\% of dry weight), protein was estimated from the elemental nitrogen $(\mathrm{N})$ and the use of nitrogen-protein conversion factor of 6.25 according to Cunniff and Washington (1997). Total carbohydrate was analyzed by using the method of Dubois et al. (1956) with the use of glucose as a standard. Lipids were extracted with a chloroform-methanol mixture $(2: 1 \mathrm{v} / \mathrm{v})$ then were dried over anhydrous sodium sulfate, after which the solvent was removed by heating at $80^{\circ} \mathrm{C}$ under vacuum (Cunniff and Washington, 1997).

\section{Fourier transforms infrared spectrometry (FTIR) of dry biomass}

The FTIR spectroscopic characterization of dry seaweeds was performed using a Mattson 5000 FTIR spectrometer. The solid algal biomasses were compressed with potassium bromide $(\mathrm{KBr})$ and their FTIR spectra were recorded at $25^{\circ} \mathrm{C}$ in a range of $400-4000 / \mathrm{cm}$.

\section{Extraction of algal biomass}

Dried algal biomass (25 g) was packed in a Soxhlet extractor. The solvent mixture methanol and hexane (1:1) was added into the flask and heated. The extraction procedure was repeated until most compounds were completely extracted. The liquid extract was then cooled, decolorized on activated charcoal, and filtered, then concentrated by using a rotary evaporator at $30^{\circ} \mathrm{C}-45^{\circ} \mathrm{C}$. The dried remnant was redissolved using $3 \mathrm{~mL}$ of dimethyl sulfoxide (DMSO) and stored at $4^{\circ} \mathrm{C}$ for subsequent use. The previous steps were repeated for each seaweed in addition to a control sample using methanol and hexane only.

\section{GC-MS of crude extracts}

The chemical nature of the three crude extracts was detected using Varian Chrompack CP-3800 GC/MS/MS-2000 equipped with split-splitless injector and DB-5.625 GC 
column (30 $\mathrm{m} \times 0.25 \mathrm{~mm}$ i.d., $0.25 \mu \mathrm{m}$-film thickness). Helium was used as a carrier gas with a flow rate of $1 \mathrm{~mL} / \mathrm{min}$.

\section{Antiviral activity}

The antiviral potent activity of the three algal extracts was tested against simian Rotavirus (RV) and Coxsackie virus B3 (CVB3) in the following manner:

\section{Cell lines and virus titers}

African green monkey kidney cells (Vero) and Rhesus monkey kidney cells (MA 104) were used for the CVB3 and RV infections, respectively. Vero cells were enriched in Dulbecco's Modified Eagle Medium (DMEM) (Merck Millipore, Germany), while the MA 104 cells were grown in Eagle's minimum essential medium (EMEM) (Merck Millipore, Germany). As previously described by Deyab et al. (2020) 10\% heat-inactivated fetal bovine serum (FBS), $100 \mu \mathrm{g} / \mathrm{mL}$ streptomycin, 1\% HEPES (4-2-hydroxyethyl-1piperazineethanesulfonic acid), and 100 units/mL penicillin were added to each medium, then they were incubated in $5 \% \mathrm{CO}_{2}$ atmosphere. For the purpose of cytotoxicity and antiviral assays, $2 \%$ of fetal bovine serum was added to each medium. For the virus titration, the DMEM and EMEM media were inoculated with CVB3 and activated RV SA-11 with trypsin $(10 \mathrm{mg} / \mathrm{mL})$ for $30 \mathrm{~min}$ at $37^{\circ} \mathrm{C}$, then the virus titers were calculated as $\mathrm{TCID}_{50} / 0.1 \mathrm{~mL}$ according to Spearman Kärber formula (Finney, 1978). The virus stocks were preserved at $-80^{\circ} \mathrm{C}$ until further use. Viruses were obtained from the Environmental virology lab (National Research Center, Egypt).

\section{Cytotoxicity assay}

A series of algal crude extract concentrations $(7.8,15.6,31.25$, $62.5,125,250,500$, and $1000 \mu \mathrm{gml}^{-1}$ ) were prepared in DMEM and EMEM media, then the cells were treated with these concentrations. Two control samples were used one containing medium only and the other using media and DMSO. According to Abid et al. (2012), the cytotoxic effect of the seaweed extracts was obtained using the MTT colorimetric technique, where absorbance was measured using an ELISA microplate reader at $540 \mathrm{~nm}$. The cytotoxic concentration $\left(\mathrm{CC}_{50}\right)$ which is the concentration of algal extract that reduces $50 \%$ of cell viability comparing to control, was obtained using the following formula [(A-BA) $\times 100$ ], where $A$ and $B$ refer to of cell control and treated cells, respectively.

\section{Antiviral activity of algal extracts against $R V$ and $C V B 3$}

Vero $\left(5 \times 10^{3}\right.$ cells/well $)$ and MA $104\left(5 \times 10^{4}\right.$ cells/well $)$ cell lines were grown in 96 well microtiter plates for $24 \mathrm{~h}$ in a $\mathrm{CO}_{2}$ incubator at $37^{\circ} \mathrm{C}$. The culture media had been withdrawn and three non-toxic concentrations from each seaweed extract were chosen to be tested against viral infections. Inhibition of cytopathic effect of virus was examined daily and estimated by the MTT as mentioned previously. The protection percentage $\left(\mathrm{EC}_{50}\right)$ was estimated as $[(\mathrm{A}-\mathrm{B}) /$ $(C-B) \times 100]$, where $A, B$, and $C$ are the readings of the spectrophotometric absorbance for the extracts with virusinfected cells, virus, and control cells, respectively. The protection percentage $\left(\mathrm{EC}_{50}\right)$ was considered as the concentration of the extract that protects $50 \%$ of treated infected cells, compared to the control cell. Therapeutic indexes (TI) of the seaweed's extracts were estimated by calculating the ratio $\mathrm{CC}_{50}$ over $\mathrm{EC}_{50}$.

\section{Antibacterial activity}

The antibacterial inhibition activity of the three crude extracts was tested against three bacterial strains namely, E. coli ATCC 8739, S. typhimurium ATCC 14028 and S. aureus ATCC 6538 (purchased from the Global bioresource center (ATCC, USA)) as follows.

\section{Percent inhibition of bacterial strains}

Bacterial strains (24 h aged) were cultivated in tryptic soy broth media TSB (Merck Millipore, Germany) and then incubated in an air incubator at $37^{\circ} \mathrm{C}$ for $24 \mathrm{~h}$. A volume of $200 \mu \mathrm{L}$ from each bacterial strain was cultured using the pour plate technique in freshly prepared sterile tryptic soy agar TSA (Merck Millipore, Germany). The plates were then treated with algal extracts using various concentrations $(12.5,25,50$, and $100 \mu \mathrm{g} / \mathrm{mL})$ with keeping untreated plate as a control. Percent of bacterial inhibition was calculated using the following formula $\%$ of inhibition of bacteria $=$ $(\mathrm{Cc}-\mathrm{Cs} / \mathrm{Cc}) \times 100$ Where's: $\mathrm{Cc}=$ Control count and the $\mathrm{Cs}=$ Count in different concentrations.

\section{Scanning electron microscopy (SEM) of bacteria}

The tested bacteria were inoculated in nutrient broth (NB) media (Merck Millipore, Germany) containing algal extract at a final concentration $(100 \mu \mathrm{g} / \mathrm{mL})$ and incubated at $37^{\circ} \mathrm{C}$ for $12 \mathrm{~h}$, control bacterial samples were included. After incubation time, the bacteria were centrifuged and fixed using a formalin-glutaraldehyde fixative $(4 \mathrm{~F} 1 \mathrm{G})$ in $0.1 \mathrm{M}$ phosphate buffer ( $\mathrm{pH} 7.4$ ), then the specimens were furthermore fixed using $1 \%$ osmium tetroxide in the same buffer. The specimens were then dehydrated using a series of acetone concentrations. A Polaron E500 sputter coater (Polaron Equipment Ltd., England) was used to coat the dried specimens and coated them with gold-palladium, then specimens examined using a scanning electron microscope (JEOL JSM 35C).

\section{Statistical analysis}

All tests were done in triplicates and the results are expressed as a mean \pm standard deviation (SD). Statistical analysis was performed by one-way ANOVA using the SPSS 11.5 for Windows.

\section{Results}

Biochemical characterization for tested seaweeds

The biochemical nature of the collected seaweeds is shown in Tab. 1. The protein content ranged between $4.75 \%$ and $6.15 \%$ of the dry weight, with the highest protein content recorded by S. filipendula. Similarly, the highest carbohydrate content was displayed by $S$. filipendula (45\%), generally carbohydrate content ranged between $45 \%$ and $33.15 \%$ of dry weight. Unlike the carbohydrates and proteins, the highest total lipid recorded by $C$. officinalis $(8.06 \%)$, while the lowest displayed by $A$. anceps (2.65\%). 
TABLE 1

Percentage (\%) \pm SD of biochemical composition of tested seaweeds

\begin{tabular}{llll}
\hline Seaweed & Protein & Lipid & Carbohydrates \\
\hline Amphiroa anceps & $5.60( \pm 2.83)$ & $2.65( \pm 0.49)$ & $33.13( \pm 0.89)$ \\
Corallina officinalis & $4.75( \pm 1.68)$ & $8.06( \pm 0.35)$ & $35.29( \pm 1.37)$ \\
Sargassum filipendula & $6.15( \pm 2.71)$ & $3.05( \pm 0.21)$ & $45.00( \pm 1.24)$ \\
\hline
\end{tabular}

FTIR characterization of seaweeds

The FTIR spectrum of A. anceps, C. officinalis and S. filipendula are shown in Figs. 1-3. Tab. 2 clarifies the distinctive absorbed bands. It is worth to mention that the strong absorption bands at $3349,3447,3438,3444$, and $3448 / \mathrm{cm}$ in different seaweeds are representing the $\mathrm{C}-\mathrm{H}, \mathrm{N}-\mathrm{H}$ and $\mathrm{O}-\mathrm{H}$ stretching, while stretching vibration of $\mathrm{CH}_{3}$ and $\mathrm{CH}_{2}$ groups cause weak band at 2923 and $2900 \mathrm{~cm}^{-1}$. The peak of the weak bands 2500$2524 / \mathrm{cm}$ that appeared in $A$. anceps and C. officinalis may match the $\mathrm{C}-\mathrm{O}$ stretching band. Meanwhile, the distinctive weak band between $2050 / \mathrm{cm}$ and $2113 / \mathrm{cm}$ indicative of $\mathrm{C}=\mathrm{N}$ was observed at all seaweeds, but it is absent in S. filipendula. However, the week absorption peaks around 1638 and $1800 \mathrm{~cm}^{-1}$ of three species are due to the $\mathrm{C}-\mathrm{O}$ stretching and NO asymmetric stretching. Other bands appear in the FTIR profiling of the macroalgal dry biomass indicating the presence of other functional groups like $\mathrm{O}-\mathrm{H}$ and $\mathrm{C}-\mathrm{O}$ bending vibration (carboxylic acid), $\mathrm{C}-\mathrm{F}$ stretching and $\mathrm{Si}-\mathrm{O}$ in the two red algae.

\section{GC-MS of the seaweed's crude extracts}

The chemicals in the three seaweed extracts were analysed by using GC-MS, and the chromatogram of the tested extracts illustrated in Figs. 4-6. A total of 54 various compounds were recognized in the three tested extracts. The recognized compounds with their common name, IUPAC name, molecular formula, retention time, \% peak area, chemical group, and bioactivity were clearly shown in Tab. 3. The characterized compounds were classified into 10 chemical groups. The identified chemical groups are Alcohols (5 compounds), aldehydes (5 compounds), amides (1 compound), hydrocarbons (4 compounds), ketones (10 compounds), esters (17 compounds), fatty acids (7 compounds), phenol ( 2 compounds), terpenes ( 2 compounds), and steroids (1 compound). A lower number of chemical compounds (12 compounds) were recognised in the crude extract of $A$. anceps than that identified in S. filipendula extract (23 compounds).

\section{Antiviral activity}

Cytotoxicity against Vero and MA 104 cell lines

Cytotoxicity of the seaweed crude extracts against Vero and MA104 cells was performed using the MTT colorimetric assay. The extracts exhibited less cytotoxicity against Vero cells more than MA104 cells (Tab. 4). Cytotoxicity of the extracts $\left(\mathrm{CC}_{50}\right)$ against Vero cells ranged between $750 \pm 7.5$ and $1293 \pm 12.3 \mu \mathrm{g} / \mathrm{L}$, while $\mathrm{CC}_{50}$ of the extracts against MA104 ranged between $600 \pm 6.8$ and $851 \pm 13.2 \mu \mathrm{g} / \mathrm{L}$. Meanwhile, the extract of $S$. filipendula showed less cytotoxic effect against Vero and MA 104 cell lines.

Antiviral activity of the extracts against CVB3 and $R V$

In the present work, we have assessed the antiviral effect of seaweed extracts on both the attachment and penetration

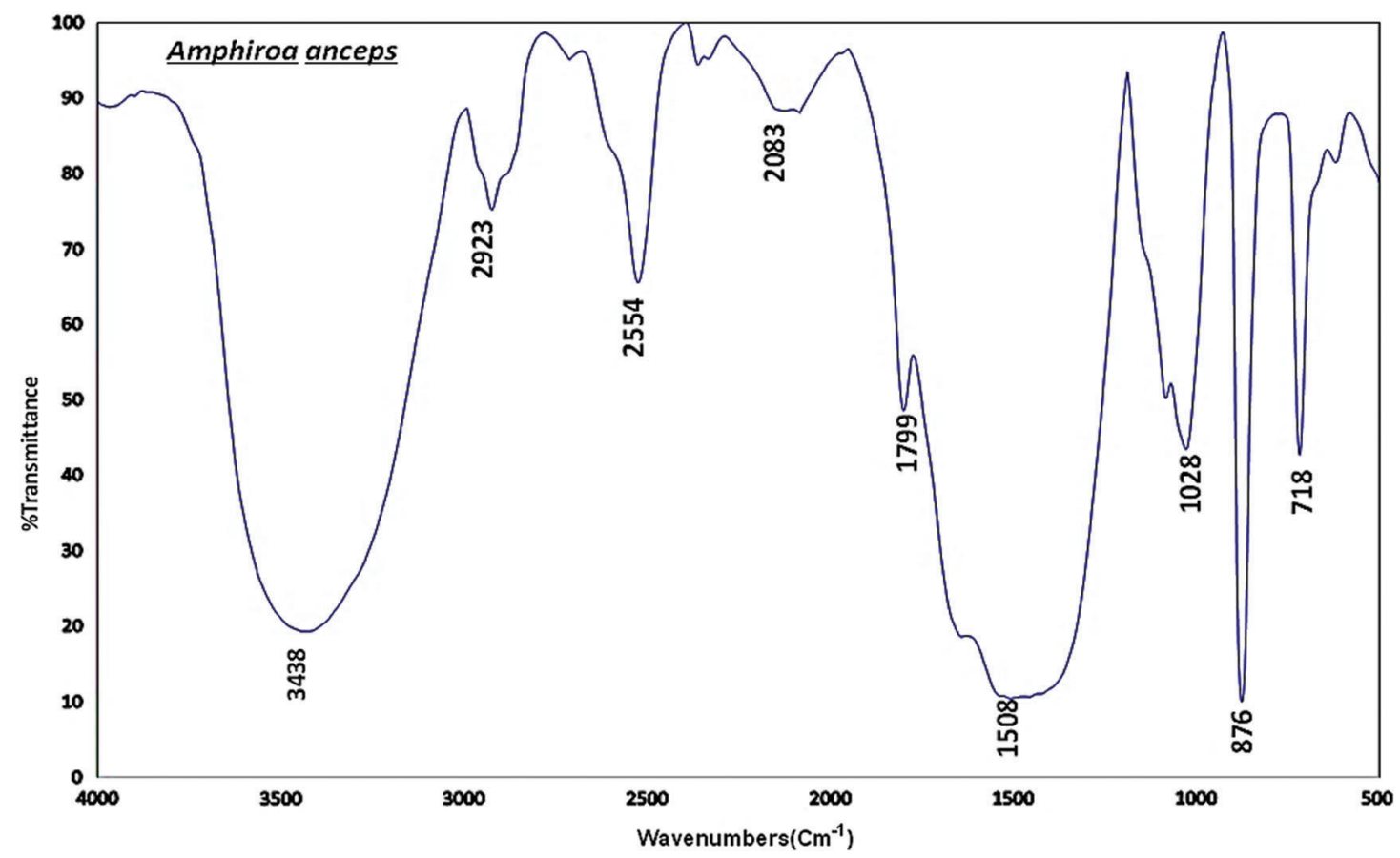

FIGURE 1. FTIR spectra of $A$. anceps. 


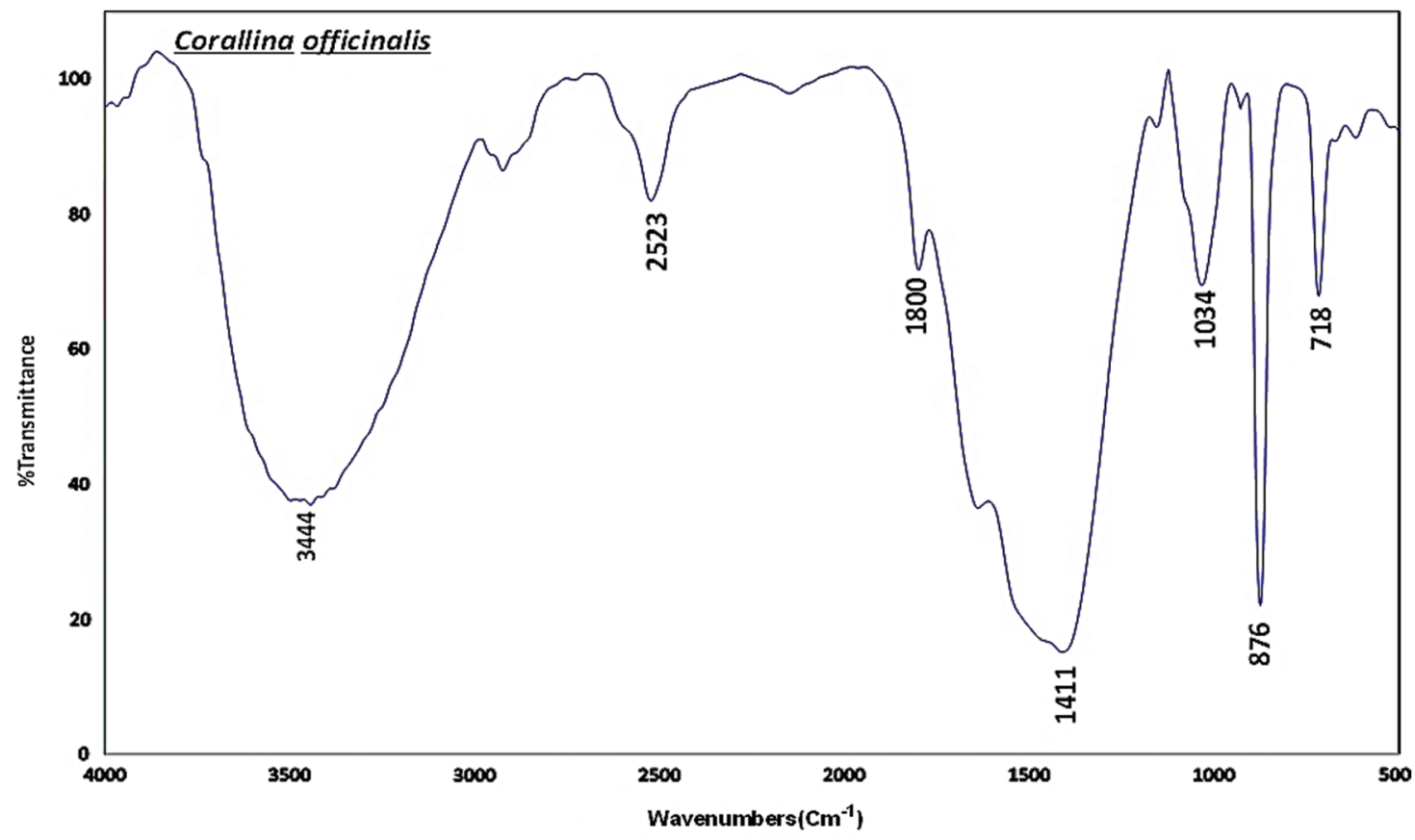

FIGURE 2. FTIR spectra of C. officinalis.

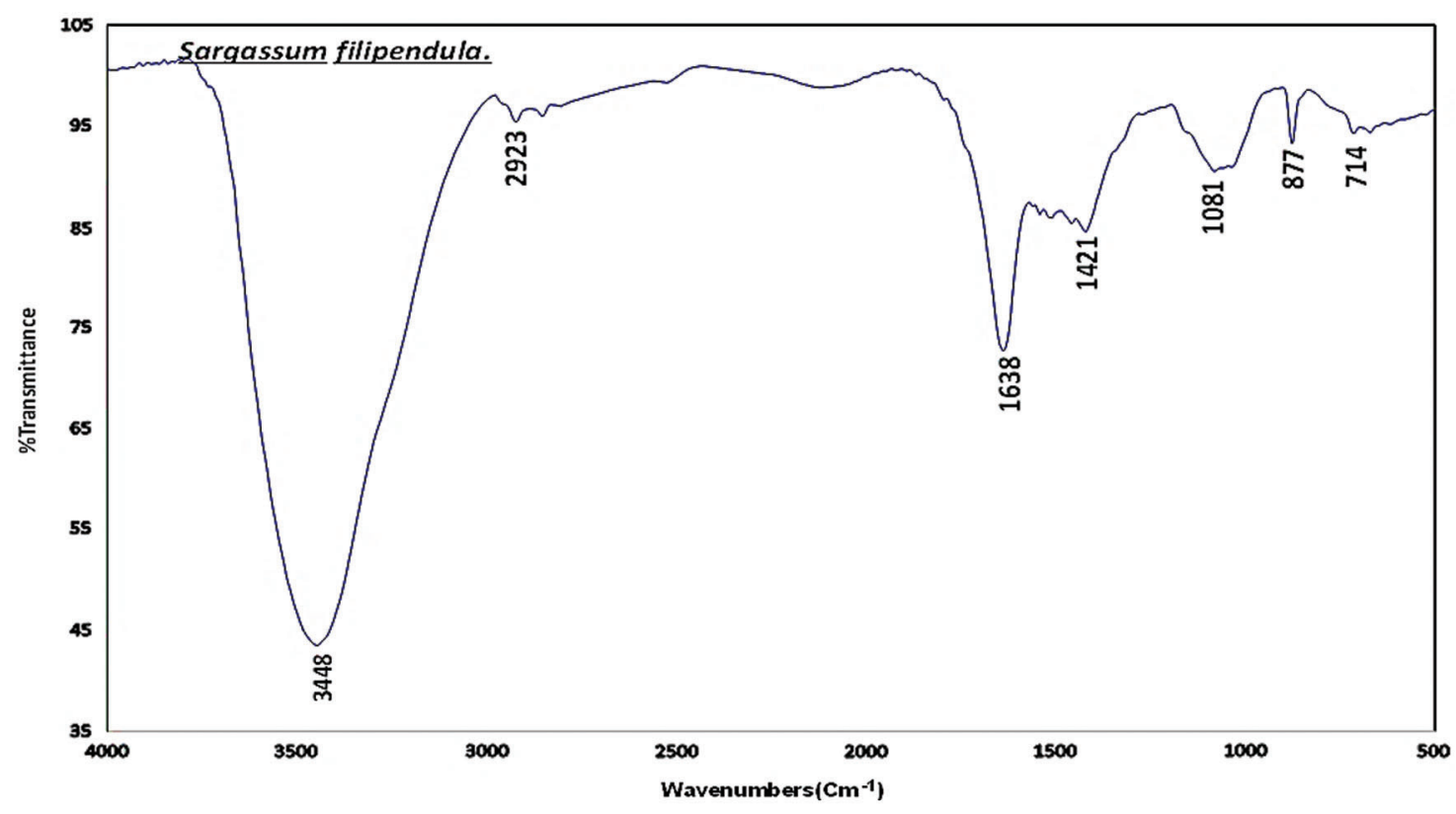

FIGURE 3. FTIR spectra of S. filipendula.

steps of viruses to the host cells. The crude extracts of seaweeds displayed good antiviral activity against CVB3 (Tab. 5 and Fig. 7). Where, the extract of A. anceps revealed the highest antiviral effect against CVB3 with TI $=15$ and it reduces viral titers by $2.5 \log \mathrm{TCID}_{50}$, while the extract of S. filipendula showed the lowest antiviral effect against CVB3 with $\mathrm{TI}=1.4$ and decrease in viral titers by $0.75 \mathrm{log}$ TCID $_{50}$. Additionally, the seaweed crude extracts showed high to moderate antiviral activity against RV (Tab. 5 and Fig. 13). The highest antiviral effect against the RV was exhibited by $A$. anceps extract with $\mathrm{TI}=22$ and reduction in viral titers by $2.75 \log \mathrm{TCID}_{50}$, followed by the extract of C. officinalis with TI $=17$ and reduction in viral titer by $2.5 \log \mathrm{TCID}_{50}$. The lowest antiviral effect against RV was displayed also by S. filipendula extract with $\mathrm{TI}=2.4$ and reduce viral titers by $1.0 \log \mathrm{TCID}_{50}$.

\section{Antibacterial activity}

\section{Inhibition of bacterial growth}

The inhibition percentage displayed by the crude extracts of the three seaweeds against S. aureus (Gram-positive), E. coli (Gram-negative), and S. typhimurium (Gram-negative) were illustrated in Figs. 8-10. The $\mathrm{IC}_{50}$ value is the concentration of the seaweed extract which causes inhibition to $50 \%$ of treated bacterial cells compared to control. It is noticeable that there were differences in antibacterial inhibition activities of the crude extracts of the three seaweeds, where each extract showed a varying degree of inhibition against 
TABLE 2

FTIR absorption frequencies $\left(\mathrm{cm}^{-1}\right)$, intensity estimation and functional group of collected seaweeds

\begin{tabular}{|c|c|c|c|c|c|c|c|}
\hline \multirow[t]{2}{*}{ Compound } & \multirow[t]{2}{*}{ Functional Groups } & \multicolumn{2}{|c|}{$\begin{array}{c}\text { Amphiroa } \\
\text { anceps }\end{array}$} & \multicolumn{2}{|c|}{$\begin{array}{l}\text { Corallina } \\
\text { officinalis }\end{array}$} & \multicolumn{2}{|c|}{$\begin{array}{l}\text { Sargassum } \\
\text { filipendula }\end{array}$} \\
\hline & & $\mathrm{Wn} / \mathrm{cm}$ & IE & $\mathrm{Wn} / \mathrm{cm}$ & IE & $\mathrm{Wn} / \mathrm{cm}$ & IE \\
\hline Polysaccharides Amino acids & $\mathrm{N}-\mathrm{H}$ Stretching $\mathrm{O}-\mathrm{H}$ Stretching & 3438 & S & 3444 & $S$ & 3448 & $\mathrm{~S}$ \\
\hline Aliphatic Compounds & $\mathrm{CH}_{3}$ and $\mathrm{CH}_{2}$ stretching & 2923 & $\mathrm{~W}$ & 2900 & $\mathrm{~W}$ & 2923 & $\mathrm{~W}$ \\
\hline phosphine & $\mathrm{C}-\mathrm{O}$ Stretching band, $\mathrm{P}-\mathrm{H}$ stretching & 2524 & $\mathrm{M}$ & 2523 & $\mathrm{~W}$ & - & \\
\hline Nitrile & cyanide stretch & 2083 & $\mathrm{~W}$ & 2100 & $\mathrm{~W}$ & - & \\
\hline Ester, Pectin & asymmetric Stretching vibration of COO- (Uronic acid) & 1799 & $\mathrm{~W}$ & 1800 & $\mathrm{~W}$ & 1638 & $\mathrm{~W}$ \\
\hline Lignin & $\mathrm{C}=\mathrm{C}$ Stretching & 1508 & $\mathrm{~W}$ & - & & - & \\
\hline Cutin & $\mathrm{C}-\mathrm{O}$ Stretching $\mathrm{O}-\mathrm{H}$ bending & - & & 1411 & $\mathrm{~S}$ & 1421 & $\mathrm{~W}$ \\
\hline Cellulose, Carbohydrates & $\begin{array}{l}\text { C-F Stretching } \\
\text { Si-O }\end{array}$ & - & & - & & 1081 & $\mathrm{~W}$ \\
\hline Starch and poly saccharides & $\mathrm{S}=\mathrm{O}$ Stretching (sulfonides) & 1028 & M & 1034 & $\mathrm{M}$ & - & \\
\hline Glucose, Galactose & Out of plane $\mathrm{C}-\mathrm{H}$ bending & 876 & S & 876 & S & 877 & $\mathrm{~W}$ \\
\hline Sulphates & C-S Stretching C=S Stretching (sulfides) & 718 & $\mathrm{M}$ & 718 & $\mathrm{M}$ & 714 & $\mathrm{~W}$ \\
\hline
\end{tabular}

Note: (Wn, wavenumbers; IE, intensity estimation; S, strong; M, medium; W, weak).

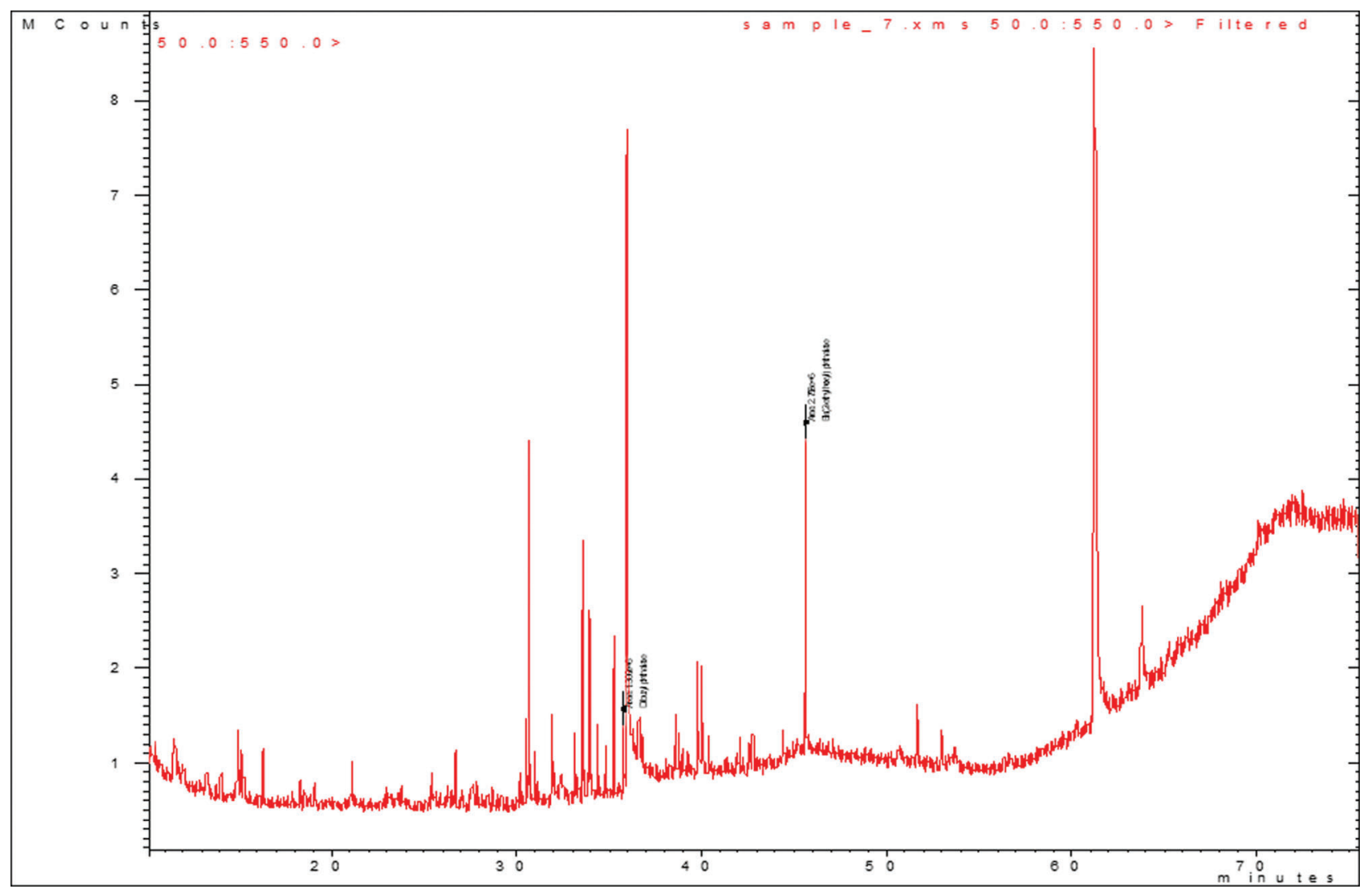

FIGURE 4. Chromatogram of $A$. anceps crude extract.

tested bacterial strains with different extracts concentrations. The highest concentration of crude extracts $(100 \mu \mathrm{g} / \mathrm{mL})$ causes mainly the maximum antibacterial inhibition activity towards the tested strains. Extract of S. filipendula showed the highest values of antibacterial activity towards E. coli with $91.4 \%$ inhibition followed by C. officinalis with $85.7 \%$ inhibition, while the extract of $A$. anceps displayed only
$57.1 \%$ inhibition against E. coil cells. The results showed that the extract of C. officinalis inhibited $100 \%$ of S. aureus cells at $100 \mu \mathrm{g} / \mathrm{mL}$ concentration followed by S. filipendula (82.5\%) and $A$. anceps (75\%). Again, the extract of C. officinalis causes the highest inhibition (80\%) against S. typhimurium, followed by both S. filipendula (65\%) and A. anceps (60\%). 
SEAWEEDS ANTIMICROBIAL ACTIVITY

253

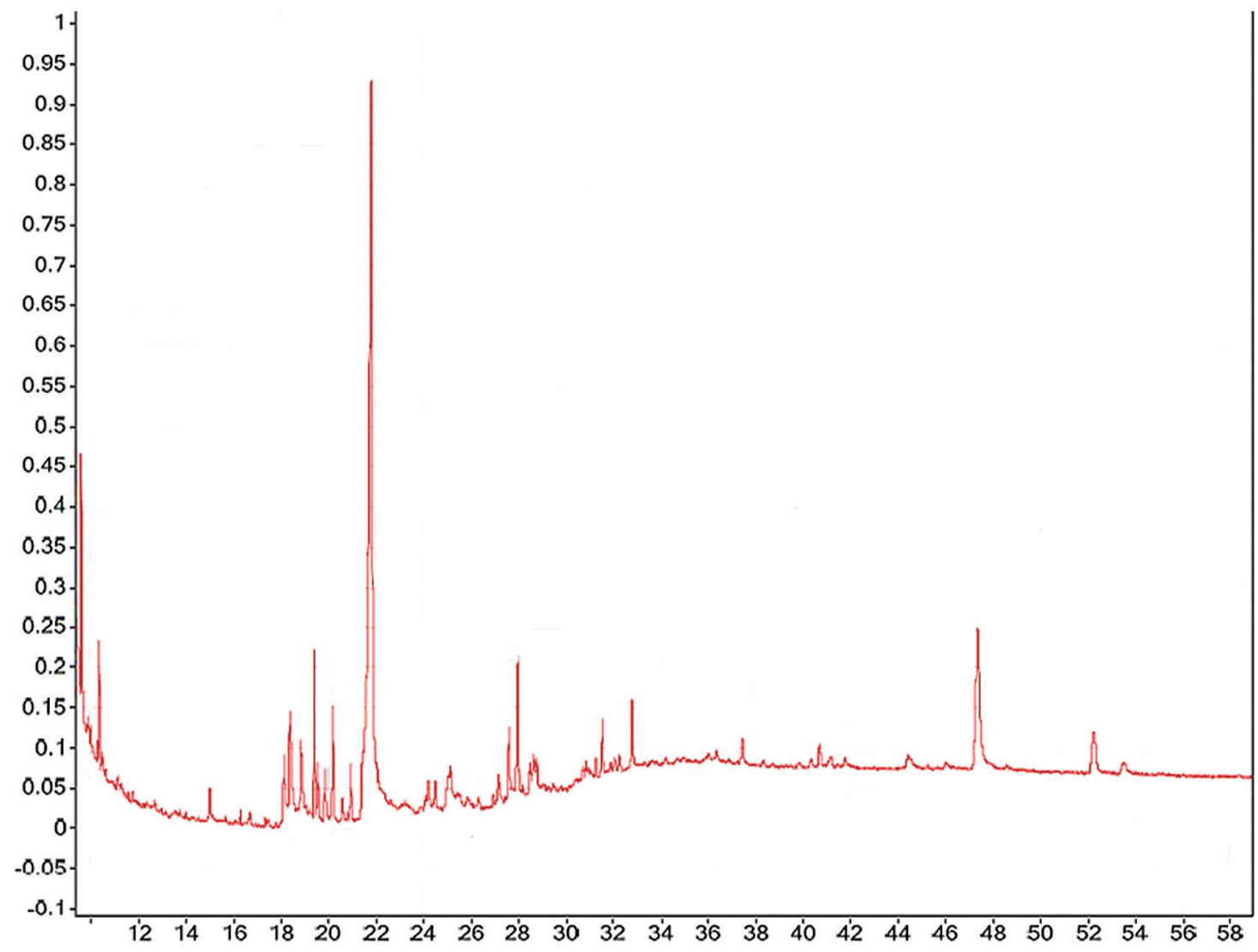

FIGURE 5. Chromatogram of C. officinalis crude extract.

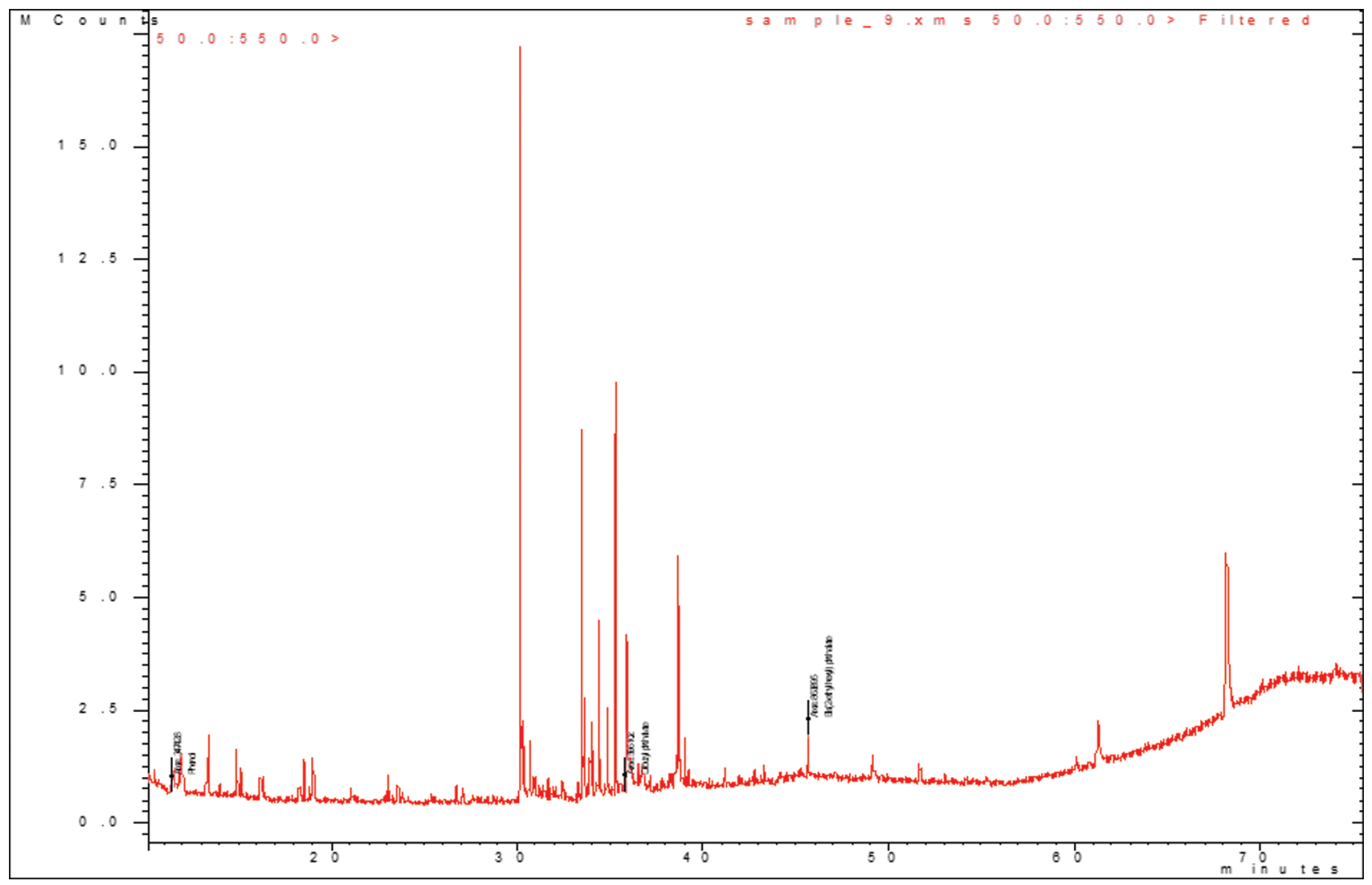

FIGURE 6. Chromatogram of S. filipendula crude extract. 
TABLE 3

Bioactive compounds present in the extracts of the tested seaweeds

\begin{tabular}{|c|c|c|c|c|c|c|}
\hline No. & Amphiroa anceps-Compounds & C.F. & R.T. & P.A.\% & C.G. & Bioactivity \\
\hline 1 & Benzoic acid, hydrazide & $\mathrm{C}_{7} \mathrm{H}_{8} \mathrm{~N}_{2} \mathrm{O}$ & 30.4 & 8.1 & Aldehyde & - \\
\hline 2 & 2(4H)-Benzofuranone, 5,6,7,7a-tetrahydro-4,4,7a-trimethyl-, (R)- & $\mathrm{C}_{11} \mathrm{H}_{16} \mathrm{O}_{2}$ & 21.9 & 2.8 & Ketone & - \\
\hline 3 & Dodecyl acrylate & $\mathrm{C}_{15} \mathrm{H}_{28} \mathrm{O}_{2}$ & 33 & 2.2 & Ketone & - \\
\hline 4 & Nonadecane & $\mathrm{C}_{19} \mathrm{H}_{40}$ & 33.9 & 5.7 & Hydrocarbon & - \\
\hline 5 & Tetradecanoic acid & $\mathrm{C}_{14} \mathrm{H}_{28} \mathrm{O}_{2}$ & 34.1 & 4.6 & Fatty acid & $\begin{array}{l}\text { Antiprotozoal \& } \\
\text { Antimicrobial }\end{array}$ \\
\hline 6 & Carbonic acid, butyl undec-10-enyl ester & $\mathrm{C}_{16} \mathrm{H}_{30} \mathrm{O}_{3}$ & 31.4 & 2.24 & Ester & \\
\hline 7 & 6,10,14-Trimethylpentadecan-2-one (Phytone) & $\mathrm{C}_{18} \mathrm{H}_{36} \mathrm{O}$ & 35.9 & 1 & Ketone & Antimicrobial \\
\hline 8 & 7,9-Di-tert-butyl-1-oxaspiro(4,5)deca-6,9-diene-2,8-dione & $\mathrm{C}_{17} \mathrm{H}_{24}$ & 36.1 & 3.4 & Ketone & Antimicrobial \\
\hline 9 & Pentadecanoic acid, 14-methyl-, methyl ester & $\mathrm{C}_{17} \mathrm{H}_{34} \mathrm{O}_{2}$ & 36.9 & 29.5 & Ester & Antimicrobial \\
\hline 10 & n-Hexadecanoic acid (Palmitic acid) & $\mathrm{C}_{16} \mathrm{H}_{32} \mathrm{O}_{2}$ & 55.4 & 7.8 & Fatty acid & $\begin{array}{l}\text { Anti-tumor \& } \\
\text { Immunostimulant }\end{array}$ \\
\hline 11 & 1,2-Benzenedicarboxylic acid, diisooctyl ester & $\mathrm{C}_{24} \mathrm{H}_{38} \mathrm{O}_{4}$ & 61.1 & 30.4 & Ester & - \\
\hline 12 & Cholesterol & $\mathrm{C}_{27} \mathrm{H}_{46} \mathrm{O}$ & 64.9 & 2 & Steroid & - \\
\hline No. & Corallina officinalis-Compounds & C.F. & R.T. & P.A.\% & C.G. & Bioactivity \\
\hline 1 & Benzoic acid, hydrazide & $\mathrm{C}_{7} \mathrm{H}_{8} \mathrm{~N}_{2} \mathrm{O}$ & 1.1 & 1.5 & Aldehyde & - \\
\hline 2 & Octadecanoic acid, 1-[(tetradecyloxy)carbonyl]pentadecyl ester & $\mathrm{C}_{48} \mathrm{H}_{94} \mathrm{O}_{4}$ & 4.9 & 1.7 & Ester & - \\
\hline 3 & Nonanal & $\mathrm{C}_{9} \mathrm{H}_{18} \mathrm{O}$ & 20.3 & 2.2 & Aldehyde & Antifungal \\
\hline 4 & Thiosemicarbazide & $\mathrm{CH}_{5} \mathrm{~N}_{3} \mathrm{~S}$ & 23.8 & 1.13 & Amide & $\begin{array}{l}\text { Anticancer, Anti- } \\
\text { protozoa \& } \\
\text { Antibacterial }\end{array}$ \\
\hline 5 & Sulfurous acid, butyl undecyl ester & $\mathrm{C}_{15} \mathrm{H}_{32} \mathrm{O}_{3} \mathrm{~S}$ & 25.6 & 2.1 & Ester & - \\
\hline 6 & 2,6-Difluorobenzoic acid, tridec-2-ynyl ester & $\mathrm{C}_{20} \mathrm{H}_{26} \mathrm{~F}_{2} \mathrm{O}_{2}$ & 26.1 & 5 & Ester & - \\
\hline 7 & Phenol, 3,5-bis(1,1-dimethylethyl)- & $\mathrm{C}_{14} \mathrm{H}_{22} \mathrm{O}$ & 27 & 1.76 & Phenol & - \\
\hline 8 & $\begin{array}{l}\text { 4,4,7a-Trimethyl-5,6,7,7a-tetrahydrobenzofuran-2(4H)-one } \\
\text { (Dihydroactinolide) }\end{array}$ & $\mathrm{C}_{11} \mathrm{H}_{16} \mathrm{O}_{2}$ & 32 & 2.26 & Ketone & Antiviral \\
\hline 9 & Tetradecanoic acid & $\mathrm{C}_{14} \mathrm{H}_{28} \mathrm{O}_{2}$ & 33.8 & 9.1 & Fatty acid & $\begin{array}{l}\text { Anti-protozoa \& } \\
\text { Antimicrobial }\end{array}$ \\
\hline 10 & Ethanol, 2-(9-octadecenyloxy)-, (Z)- & $\mathrm{C}_{20} \mathrm{H}_{40} \mathrm{O}_{2}$ & 34.6 & 3.1 & Alcohol & - \\
\hline 11 & 3,7,11,15-Tetramethyl-2-hexadecen-1-ol (Phytol) & $\mathrm{C}_{20} \mathrm{H}_{40} \mathrm{O}$ & 35.1 & 3 & Terpene & $\begin{array}{l}\text { Antimicrobial and } \\
\text { Source of vitamin K }\end{array}$ \\
\hline 12 & $\begin{array}{l}\text { 1,2-Benzenedicarboxylic acid, bis(2-methylpropyl) ester } \\
\text { (DIISOBUTYL PHTHALATE) }\end{array}$ & $\mathrm{C}_{16} \mathrm{H}_{22} \mathrm{O}_{4}$ & 35.4 & 6.1 & Ester & - \\
\hline 13 & 7,9-Di-tert-butyl-1-oxaspiro(4,5)deca-6,9-diene-2,8-dione & $\mathrm{C}_{17} \mathrm{H}_{24}$ & 35.8 & 8.1 & Ketone & - \\
\hline 14 & Pentadecanoic acid, 14-methyl-, methyl ester & $\mathrm{C}_{17} \mathrm{H}_{34} \mathrm{O}_{2}$ & 36.8 & 1.7 & Ester & Antimicrobial \\
\hline 15 & $\begin{array}{l}\text { Ethaneperoxoic acid, 1-cyano-1-[2-(2-phenyl-1,3-dioxolan-2-yl) } \\
\text { ethyl]pentyl ester }\end{array}$ & $\mathrm{C}_{19} \mathrm{H}_{25} \mathrm{NO}_{5}$ & 39.5 & 3.1 & Ester & - \\
\hline 16 & Hexadecane, 1,1-bis(dodecyloxy)- & $\mathrm{C}_{40} \mathrm{H}_{82} \mathrm{O}_{2}$ & 40 & 3 & Hydrocarbon & - \\
\hline 17 & 1-Nonadecanol & $\mathrm{C}_{19} \mathrm{H}_{40} \mathrm{O}$ & 41.5 & 3.7 & Alcohol & $\begin{array}{l}\text { Antibacterial \& } \\
\text { Antimicrobial }\end{array}$ \\
\hline 18 & $\begin{array}{l}\text { Methyl (5Z,8Z,11Z,14Z)-icosa-5,8,11,14-tetraenoate (Methyl } \\
\text { arachidonate) }\end{array}$ & $\mathrm{C}_{21} \mathrm{H}_{34} \mathrm{O}_{2}$ & 45.9 & 2.6 & Ester & Antimicrobial \\
\hline 19 & 1,2-Benzenedicarboxylic acid, diisooctyl ester & $\mathrm{C}_{24} \mathrm{H}_{38} \mathrm{O}_{4}$ & 60.2 & 38.2 & Ester & - \\
\hline
\end{tabular}


Table 3 (continued).

\begin{tabular}{|c|c|c|c|c|c|c|}
\hline No. & Sargassum filipendula-Compound & C.F. & R.T. & P.A.\% & C.G. & Bioactivity \\
\hline 1 & Acetic acid, 2-(2-acetoxy-2,5,5,8a-tetramethyldecalin-1-yl)- & $\mathrm{C}_{18} \mathrm{H}_{30} \mathrm{O}_{4}$ & 14.98 & 3.8 & Aldehyde & - \\
\hline 2 & Oleic Acid & $\mathrm{C}_{18} \mathrm{H}_{34} \mathrm{O}_{2}$ & 18.12 & 1.07 & Fatty acid & Anticancer \\
\hline 3 & Ppropiolic acid, 3-(1-hydroxy-2-isopropyl-5-methylcyclohexyl)- & $\mathrm{C}_{13} \mathrm{H}_{20} \mathrm{O}_{3}$ & 18.37 & 0.46 & Fatty acid & - \\
\hline 4 & Dihydroxanthin & $\mathrm{C}_{17} \mathrm{H}_{24} \mathrm{O}_{5}$ & 18.84 & 0.3 & Ketone & - \\
\hline 5 & Ethanol, 2-(9-octadecenyloxy)-, (Z)- & $\mathrm{C}_{20} \mathrm{H}_{40} \mathrm{O}_{2}$ & 19.4 & 3.07 & Alcohol & - \\
\hline 6 & Cholestan-3-ol, 2-methylene-, $(3 \beta, 5 \alpha)$ - & $\mathrm{C}_{28} \mathrm{H}_{48} \mathrm{O}$ & 19.53 & 4 & Terpene & - \\
\hline 7 & 13-Heptadecyn-1-ol & $\mathrm{C}_{17} \mathrm{H}_{32} \mathrm{O}$ & 19.84 & 5.5 & Alcohol & - \\
\hline 8 & 1-Heptatriacotanol & $\mathrm{C}_{37} \mathrm{H}_{76} \mathrm{O}$ & 20.58 & 1.38 & Alcohol & - \\
\hline 9 & $\begin{array}{l}\text { Cyclopropanebutanoic acid, 2-[[2-[[2-[(2-pentylcyclopropyl) } \\
\text { methyl]cyclopropyl]methyl]cyclopropyl]methyl]-, methyl ester }\end{array}$ & $\mathrm{C}_{25} \mathrm{H}_{42} \mathrm{O}_{2}$ & 20.93 & 3.8 & Ester & - \\
\hline 10 & n-Hexadecanoic acid & $\mathrm{C}_{16} \mathrm{H}_{32} \mathrm{O}_{2}$ & 21.78 & 0.76 & Fatty acid & $\begin{array}{l}\text { Antitumor \& } \\
\text { Antiviral }\end{array}$ \\
\hline 11 & 9,12,15-Octadecatrienoic acid, 2,3-dihydroxypropyl ester, (Z,Z,Z)- & $\mathrm{C}_{21} \mathrm{H}_{36} \mathrm{O}_{4}$ & 24.21 & 0.46 & Ester & - \\
\hline 12 & Octadecanal, 2-bromo- & $\mathrm{C}_{18} \mathrm{H}_{35} \mathrm{BrO}$ & 24.5 & 32.5 & Hydrocarbon & - \\
\hline 13 & 9-Hexadecenoic acid & $\mathrm{C}_{16} \mathrm{H}_{30} \mathrm{O}_{2}$ & 25.1 & 0.92 & Fatty acid & Anticancer \\
\hline 14 & Docosahexaenoic acid, 1,2,3-propanetriyl ester & $\mathrm{C}_{69} \mathrm{H}_{98} \mathrm{O}_{6}$ & 27.15 & 0.61 & Ester & - \\
\hline 15 & Dasycarpidan-1-methanol, acetate (ester) & $\mathrm{C}_{20} \mathrm{H}_{26} \mathrm{~N}_{2} \mathrm{O}_{2}$ & 27.59 & 12.2 & Ester & - \\
\hline 16 & Retinoic acid, methyl ester & $\mathrm{C}_{21} \mathrm{H}_{30} \mathrm{O}_{2}$ & 27.95 & 3.3 & Ester & Antitumor \\
\hline 17 & $\begin{array}{l}\text { 5H-Cyclopropa[3,4]benz[1,2-e]azulen-5-one, 9-(acetyloxy)-3- } \\
{[(\text { acetyloxy)methyl]-1,1a,1b,4,4a,7a,7b,8,9,9a-deca }}\end{array}$ & $\mathrm{C}_{24} \mathrm{H}_{32} \mathrm{O}_{8}$ & 28.49 & 2.3 & Ketone & - \\
\hline 18 & $\begin{array}{l}\text { 2-[4-methyl-6-(2,6,6-trimethylcyclohex-1-enyl)hexa-1,3,5- } \\
\text { trienyl]cyclohex-1-en-1-carboxaldehyde }\end{array}$ & $\mathrm{C}_{23} \mathrm{H}_{32} \mathrm{O}$ & 28.62 & 8 & Aldehyde & - \\
\hline 19 & Dasycarpidan-1-methanol, acetate (ester) & $\mathrm{C}_{20} \mathrm{H}_{26} \mathrm{~N}_{2} \mathrm{O}_{2}$ & 28.77 & 2 & Ester & - \\
\hline 20 & $\begin{array}{l}\text { 5H-Cyclopropa[3,4]benz[1,2-e]azulen-5-one, 4,9,9a-tris } \\
\text { (acetyloxy)-3-[(acetyloxy)methyl]-1,1a,1b,4,4a,7a,7b,8,9, }\end{array}$ & $\mathrm{C}_{28} \mathrm{H}_{36} \mathrm{O}_{11}$ & 31.26 & 1.4 & Ketone & - \\
\hline 21 & Phen-1,4-diol, 2,3-dimethyl-5-trifluoromethyl- & $\mathrm{C}_{9} \mathrm{H}_{9} \mathrm{~F}_{3} \mathrm{O}_{2}$ & 31.53 & & Phenol & - \\
\hline 22 & $\begin{array}{l}\text { 5H-Cyclopropa[3,4]benz[1,2-e]azulen-5-one, 9a-(acetyloxy)- } \\
\text { 1,1a,1b,4,4a,7a,7b,8,9,9a-decahydro-4a,7b,9-trihyd }\end{array}$ & $\mathrm{C}_{22} \mathrm{H}_{30} \mathrm{O}_{7}$ & 32.77 & - & Ketone & - \\
\hline 23 & $\begin{array}{l}\text { Acetic acid, 3-hydroxy-4,4,10,13-tetramethyl-7-oxo- } \\
2,3,4,7,8,9,10,11,12,13,14,15,16,17 \text {-tetradecahydro- } 1 \mathrm{H} \text {-cyclo }\end{array}$ & $\mathrm{C}_{23} \mathrm{H}_{34} \mathrm{O}_{4}$ & 37.42 & - & Hydrocarbon & - \\
\hline
\end{tabular}

Note: (C.F., Chemical formula; R.T., Retention time(min); P.A\%, percent peak area; Bioactivity, Biological activity).

TABLE 4

Cytotoxicity \pm SD of Seaweeds extracts against Vero and MA 104 cells

\begin{tabular}{lll}
\hline Extracts of Seaweeds & \multicolumn{2}{c}{$\mathbf{C C}_{\mathbf{5 0}}(\boldsymbol{\mu g} / \mathbf{m L})$} \\
\cline { 2 - 3 } & Vero Cells & MA 104 Cells \\
\hline Amphiroa anceps & $780 \pm 8.7$ & $670 \pm 9.2$ \\
Corallina officinalis & $750 \pm 7.5$ & $600 \pm 6.8$ \\
Sargassum filipendula & $1293 \pm 12.3$ & $851 \pm 13.2$ \\
\hline
\end{tabular}

Scanning electron microscopy of the bacteria

As a result of the bactericidal activity of the three seaweeds crude extracts, the morphology of the tested bacterial cells was compared to control after treating the bacterial cells with $100 \mu \mathrm{g} / \mathrm{mL}$ of each extract for $12 \mathrm{~h}$ using scanning electron microscopy. The cytomorphology of E. coli control was apparently normal rods with a well-defined rigid and smooth surface, while the treated E. coli cell consisted of most degraded cells which appeared shrunk, ragged, wrinkled, several dents and holes were also distinguished on the surface of the cells, in addition to that, some cells were appeared empty with hollow ends (Fig. 11). 
TABLE 5

Antiviral activity of Seaweeds extracts against CVB3 and RV determined by MTT and Kärber Method

\begin{tabular}{llllll}
\hline Extracts of Seaweeds & \multicolumn{2}{c}{ CV B3 } & & \multicolumn{2}{c}{ RV (SA-11) } \\
\cline { 2 - 5 } & $\mathbf{E C}_{\mathbf{5 0}} \mathbf{a}^{\mathbf{a}}$ & $\mathbf{T I}^{\mathbf{b}}$ & $\mathbf{E C}_{\mathbf{5 0}}$ & TI \\
\hline Amphiroa anceps & 52 & 15 & 30.5 & 22 \\
Corallina officinalis & 85.2 & 8.8 & 32.7 & 18.3 \\
Sargassum filipendula & 924 & 1.4 & 353.3 & 2.4 \\
\hline
\end{tabular}

Note: a Concentration of extract that inhibits viral infectivity (Cytopathic Effect) by $50 \%$.

${ }^{\mathrm{b}}$ Therapeutic index $=\mathrm{CC}_{50} / \mathrm{EC}_{50}$. Values are given as the mean from triplicate experiments.

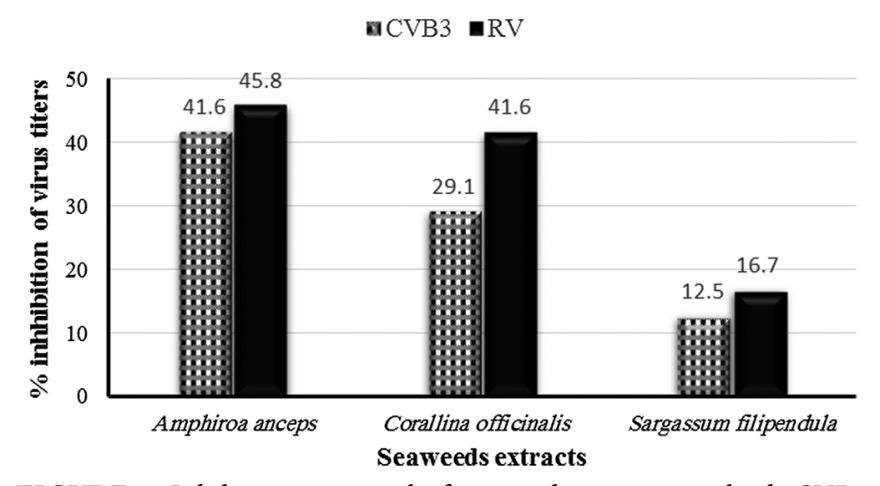

FIGURE 7. Inhibitory potential of seaweeds extracts on both CVB3 and RV infections.

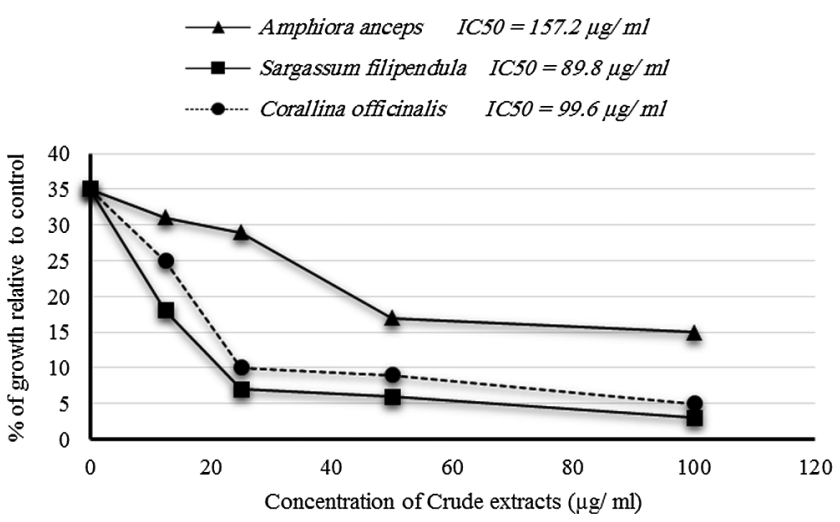

FIGURE 8. The inhibition of $E$. coli growth comparing to control via different extracts.

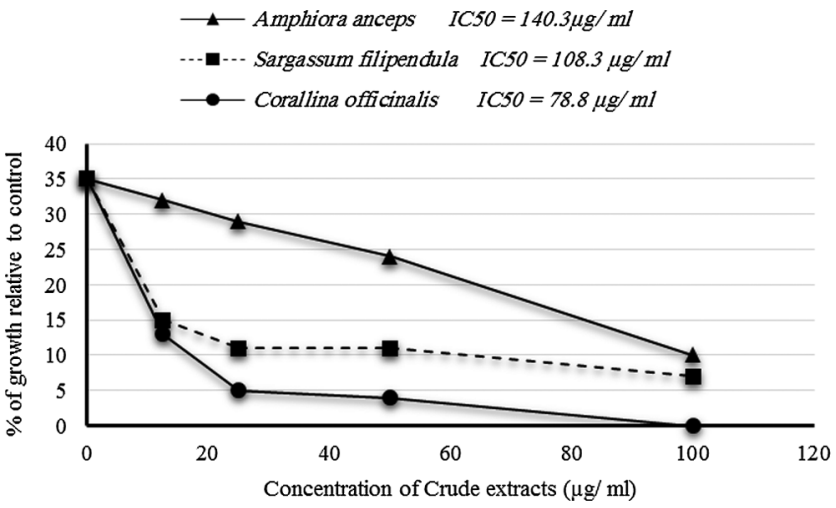

FIGURE 9. The inhibition of $S$. aureus growth comparing to control via different extracts.

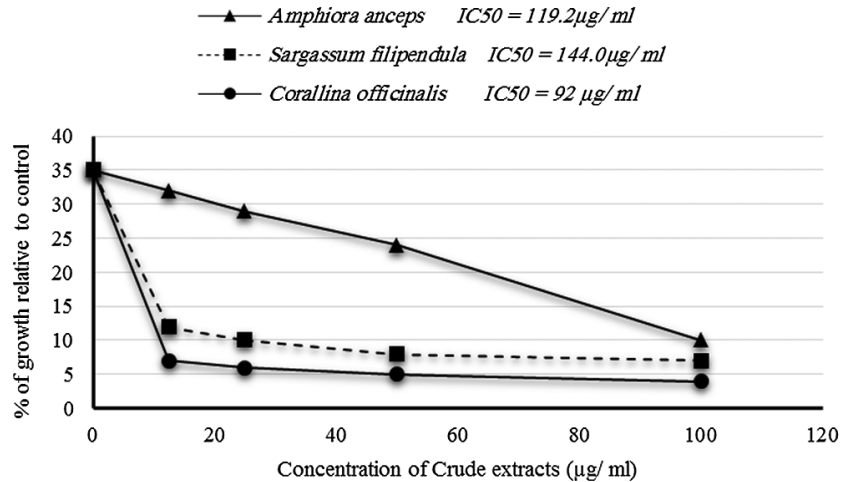

FIGURE 10. The inhibition of $S$. typhimurium growth comparing to control via different extracts.

The cytomorphology of $S$. aureus control apparently indicated the presence of normal straight spherical cells and adhering together by the smooth surface, the extracts influenced the treated bacterial cells to be malformed, enlarged with tiny holes and dents on the cell surfaces, for most of the bacterial population, and few viable cells with a rigid outline and smooth surface remained (Fig. 12). However, the control cells of S. typhimurium were rod-like bacilli with a smooth surface and rigid well-defined shape, unlike the treated cells which appeared elongated, enlarged, and malformed, most of the cell population consisted of most degraded cells which appeared ragged, wrinkled, and shrunk (Fig. 13).

\section{Discussion}

Algae specially macroalgae have been a valuable source for a group of valuable metabolites such as vitamins, enzymes, proteins, lipids, carotenoids, polysaccharides, sterols, antibiotics in addition to a lot of fine chemicals (Deyab et al., 2020; Mofeed et al., 2019). In this regard, many secondary and primary metabolites produced by macroalgae (Seaweeds) organisms may be of importance in pharmaceutical industries (Mofeed et al., 2019). The present work represents a comprehensive study that focused on searching for new therapeutic alternatives that displayed antimicrobial (antiviral and antibacterial) activities. To achieve this goal, the crude extract of three seaweeds species namely $A$. anceps, $C$. officinalis and S. filipendula were assayed in vitro for their antiviral activity against two human viruses (Rotavirus and Coxsackie virus B3), and also for their antibacterial properties against three pathogenic bacteria (S. typhimurium, S. aureus 

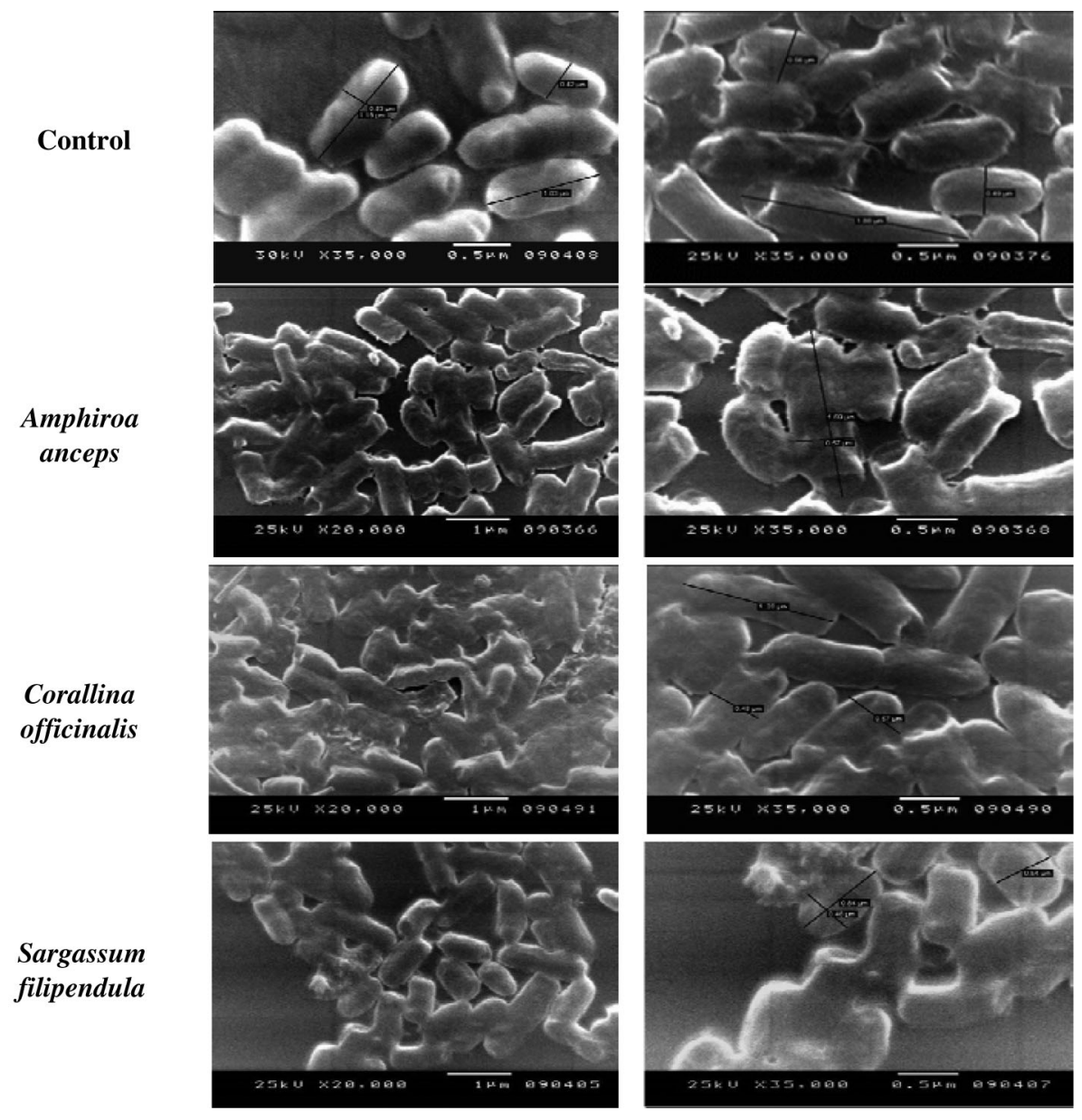

FIGURE 11. SEM micrographs of E. coli cytomorphology before (control) and after treatment with the extracts.

and E. coli). The identity of the collected seaweeds in the present study was done by morphological characterization and confirmed by microscopic examination of its edges. In this regard, three seaweeds were collected from different habitats two were Rhodophyta (A. anceps and C. officinalis) while $S$. filipendula belonging to Phaeophyta. The present investigation paid great attention to the biochemical characterization of collecting seaweeds; a high diversity of the biochemical nature of seaweeds paves the path to explore a variety of compounds in their body composition.

Generally, carbohydrates represent the major biochemical component in the three seaweeds, this may be due to higher pyrocollodion content in their cell walls (Ismail and Mohamed, 2017; Mendis and Kim, 2011). The changes in the biochemical content may be spatial or temporal but dominantly attributed to water quality (Dave and Parekh, 1975). In the present study, the FTIR results of the crude seaweeds indicated the presence of various chemical functional groups which hinted the presence of many metabolic active products, these results come inconsistency with previous work by Demir et al. (2015), Guerrero et al. (2013), Moustafa et al. (2018) and Singh et al. (2016). The GC-MS analysis of the crude extract of different seaweeds showed the presence of chemical substances with previously known antimicrobial activity effective. Molecules such as tetradecanoic acid, 6,10,14trimethylpentadecan-2-one (Phytone), pentadecanoic acid, 7,9-di-tert-butyl-1-oxaspiro (4,5) deca-6,9-diene-2,8-dione, 14-methyl-methyl ester, nonanal, thiosemicarbazide, 1-nonadecanol and methyl (5Z,8Z,11Z,14Z)-icosa-5,8,11,14tetraenoate (methyl arachidonate) are known for their antimicrobial activities (Ding et al., 2014; Ertas et al., 2015; Temiz et al., 2015). Dihydroactinolide (4,4,7atrimethyl-5,6,7,7a-tetrahydrobenzofuran-2(4H)-one), and n-hexadecanoic acid are compounds known for their antiviral activity found in C. officinalis and S. filipendula crude extracts, respectively (Librán-Pérez et al., 2019; Shilova et al., 2012). The fast development of microbial resistance encouraged researchers to innovate a variety of antibiotics and novel drugs, especially those involved in the treatment of infectious diseases. The cited results revealed that, the three crude extracts displayed a high antibacterial effective against $S$. aureus, $S$. typhimurium and E. coli, these results come inconsistency with that recorded by AbdelKhaliq et al. (2014), and Taskin et al. (2007) who noted the antimicrobial inhibiting activity of crude extracts of some seaweeds against a lot of pathogenic bacteria especially $S$. aureus and E. coli. Despite Many efforts to prevent and/or control RV and CVB3 infections, these infections still affect millions of children worldwide particularly in developing countries (Kalsi and Etzler, 2000). In this line, the present investigation represents an attempt to study the antiviral activity of extracts of three seaweeds against Coxsackie virus B3 and simian Rotavirus (RV). The cycle of viral replication implicates series of steps; attachment, penetration, and replication of the genetic materials, then assembly, followed 


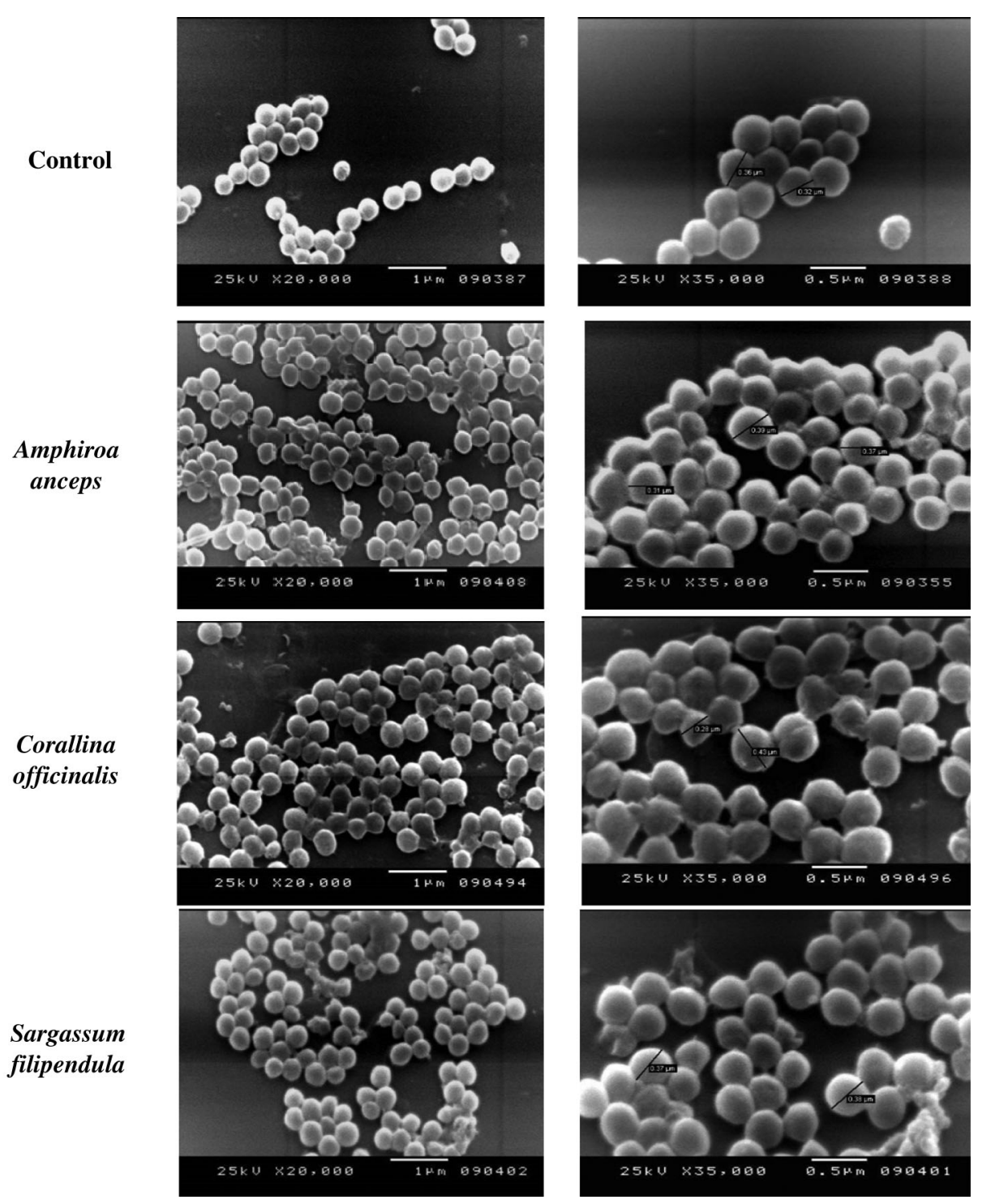

FIGURE 12. SEM micrographs of $S$. aureus cytomorphology before (control) and after treatment with the extracts. by liberation from host cells. These steps can be used as targets of anti-Coxsackie virus B3 and anti-rotavirus agents (Shaheen et al., 2015).

In this work, we determined the impact of tested extracts on the attachment and penetration steps. All seaweeds extract exhibited a low cytotoxic effect against Vero and MA 104 cell lines, and these results are in accordance with that reported by Morán-Santibañez et al. (2018) who find that, CC $_{50}$ of the Ulva intestinalis extract was more than $1500 \mu \mathrm{g} / \mathrm{mL}$. Extracts of $A$. anceps and $C$. officinalis displayed a high antiviral effect on RV with TI values $22,18.3$ and cause high inhibition in virus titers with 45.8 and $41.6 \%$, respectively. In line with that, the extracts of $A$. anceps and $C$. officinalis showed lower anti-viral activities against
CVB3 with TI values of 15 and 8.8 , and inhibition of virus titers with 41.6 and $29.1 \%$, respectively. In a previous study, Soares et al. (2012) demonstrated that seaweed extract has antiviral activities against the herpes simplex virus (HSV), also Shi et al. (2017) and MoránSantibañez et al. (2018) described that, the algal secondary metabolites have been tested as antiviral agents as a prophylactic strategy before viral infection and also as an effective treatment after infection to avoid infection dissemination. There are limited previous studies about the antiviral activities of seaweed extracts against both RV and CVB3, therefore these results may be considered as a pioneer record of the antiviral impact of Seaweed extracts towards CVB3 and RV. 


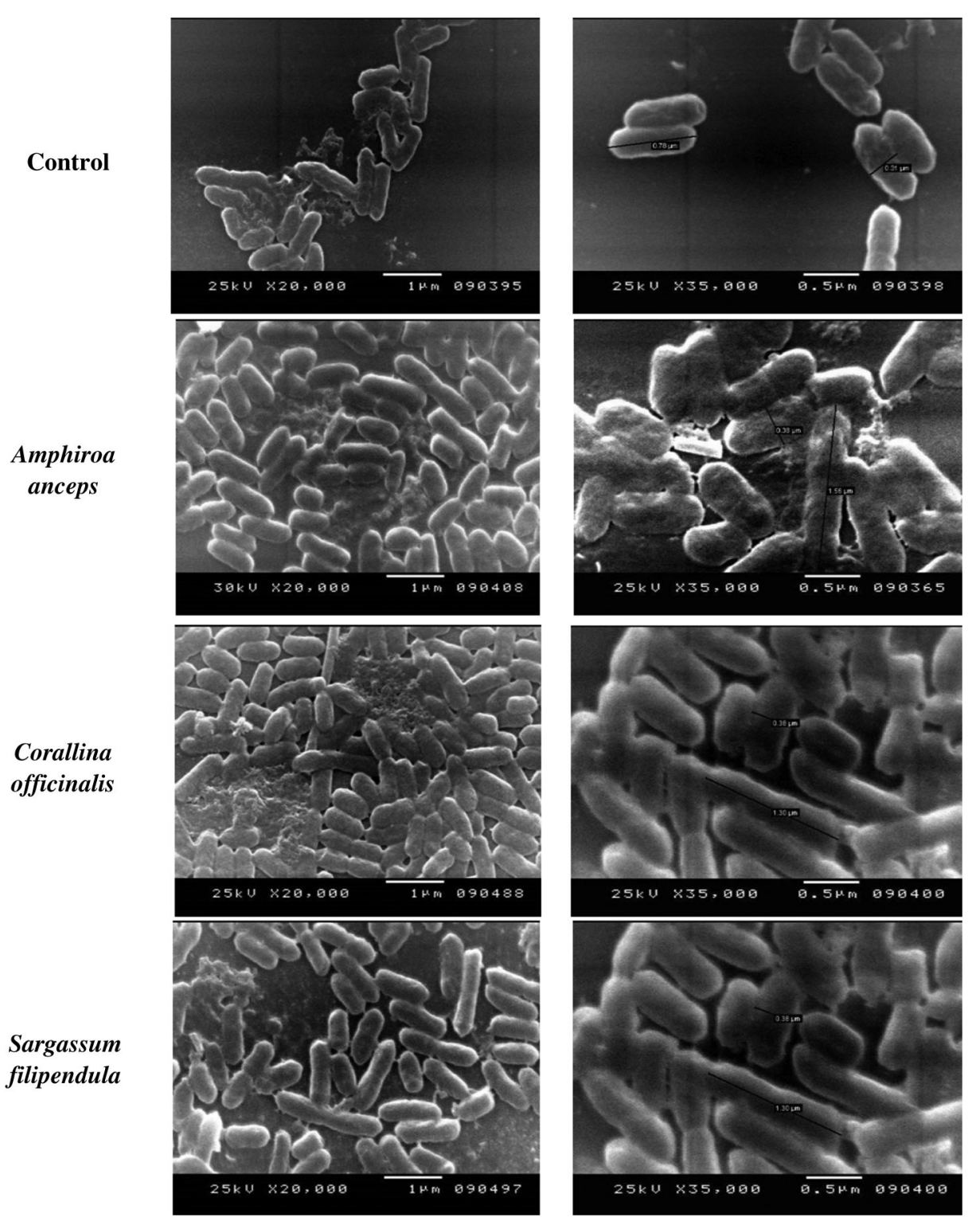

FIGURE 13. SEM micrographs of $S$. typhimurium cytomorphology before (control) and after treatment with the extracts.

\section{Conclusion}

In conclusion, the present results proved that the extract of three weeds namely $A$. anceps, $C$. officinalis and $S$. filipendula possess an effective antibacterial activity against $S$. typhimurium, $S$. aureus and E. coli pathogenic bacteria and showed antiviral activity against CVB3 and RV infections and can be used as pretreatment for their infections by attaching to the capsids to prevent the connection with the cell receptors and thereby stop their penetration into host cells. The promising results together with the simple and cost-effective extraction method make the tested seaweeds as an opportune source of antiviral and antibacterial drugs, but more in vivo studies are needed to evaluate the antimicrobial activities of these seaweeds.

Availability of Data and Materials: All data generated or analyzed during this study are included in the manuscript.

Authors' Contribution: The authors confirm contribution to the paper as follows: Design and study conception: JM and MD. Draft manuscript preparation: JM and EE-B. Data collection and supervising the practical work: AM. Writing some parts of the article, revise the final version and submit it for publication: MM. Writing some parts of the article, revise the final version: $\mathrm{SN}$. Morphological and molecular identification as well as cultivation of the microbe: EE-B. All authors reviewed the results and approved the final version of the manuscript.

Funding Statement: Authors would like to thank the Deanship of Scientific Research at King Khalid University, Kingdom of Saudi Arabia for Funding (G.R.P./80/42).

Conflicts of Interest: The authors declare that they have no conflicts of interest to report regarding the present study.

\section{References}

Abdel-Khaliq A, Hassan H, Rateb ME, Hammouda O, Science G (2014). Antimicrobial activity of three Ulva species collected from some Egyptian Mediterranean seashores. International Journal of Engineering Research 2: 648-669.

Abid N, Rouis Z, Lassoued M, Sfar S, Aouni M (2012). Assessment of the cytotoxic effect and in vitro evaluation of the antienteroviral activities of plants rich in flavonoids. Journal of Applied Pharmaceutical Science 2: 74. 
Al-Fadhli A, Wahidulla S, D’souza L (2006). Glycolipids from the red alga Chondria armata (Kutz.) Okamura. Glycobiology 16: 902-915.

Aslam A, Fazal T, Zaman Q, Shan A, Rehman F, Iqbal J, Rashid N, Rehman M (2020). Biorefinery of microalgae for nonfuel products. Microalgae Cultivation for Biofuels Production. pp. 197-209. Academic Press.

Brodie J, Wilbraham J, Pottas J, Guiry MD (2016). A revised checklist of the seaweeds of Britain. Journal of the Marine Biological Association of the United Kingdom 96: 1005.

Brito T, Barros F, Silva R, Júnior G, Júnior J, Franco Á, de Paula R (2016). Sulfated polysaccharide from the marine algae Hypnea musciformis inhibits TNBS-induced intestinal damage in rats. Carbohydrate Polymers 151: 957-964.

Cunniff P, Washington D (1997). Official methods of analysis of AOAC International. Journal of AOAC International 80: 127A.

Dave M, Parekh R (1975). Protein content of green seaweeds from Saurashtra coast. Salt Research India 11: 41-44.

de Clerck O, Coppejans E (1996). Marina Algae of the Jubail Marine Wildlife Sanctuary, Saudi Arabia. Citeseer.

Demir P, Onde S, Severcan F (2015). Phylogeny of cultivated and wild wheat species using ATR-FTIR spectroscopy. Spectrochimica Acta Part A: Molecular and Biomolecular Spectroscopy 135: 757-763.

Deyab M, Mofeed J, El-Bilawy E, Ward F (2020). Antiviral activity of five filamentous cyanobacteria against coxsackievirus B3 and rotavirus. Archives of Microbiology 202: 213-223.

Ding H, Zhu T, Yin X, Liu J, Zhang L, et al. (2014). Pyrrolidine dithiocarbamate protects pancreatic $\beta$-cells from oxidative damage through regulation of FoxO1 activity in type 2 diabetes rats. Acta Biochimica et Biophysica Sinica 46: 582-589.

Dubois M, Gilles K, Hamilton J, Roberts P, Smith F (1956). Phenol sulphuric acid method for carbohydrate determination. Annalen der Chemie 28: 350-359.

El-Baroty G, Moussa M, Shallan M, Ali M, Sabh A, Shalaby E (2007). Contribution to the aroma, biological activities, minerals, protein, pigments and lipid contents of the red alga: Asparagopsis taxiformis (Delile) Trevisan. Journal of Applied Sciences Research 3: 1825-1834.

Ertas A, Yilmaz MA, Firat M (2015). Chemical profile by LC-MS/MS, GC/MS and antioxidant activities of the essential oils and crude extracts of two Euphorbia species. Natural Product Research 29: 529-534.

Fakayode OA, Aboagarib EAA, Zhou C, Ma H (2020). Co-pyrolysis of lignocellulosic and macroalgae biomasses for the production of biochar-A review. Bioresource Technology 297: 122408.

Finney D (1978). Statistical method in biological assay. vol. 3. New York: Macmillan Publishing Co., Inc.

Guerrero P, Garrido T, Leceta I, de La Caba K (2013). Films based on proteins and polysaccharides: Preparation and physicalchemical characterization. European Polymer Journal 49: 3713-3721.

Ismail M, Mohamed S (2017). Differentiation between some Ulva spp. by morphological, genetic and biochemical analyses. Вавиловский журнал генетики и селекции 21: 360-367.

Kalsi G, Etzler ME (2000). Localization of a Nod factor-binding protein in legume roots and factors influencing its distribution and expression. Plant Physiology 124: 1039-1048.

Khalafi T, Buazar F, Ghanemi K (2019). Phycosynthesis and enhanced photocatalytic activity of zinc oxide nanoparticles toward organosulfur pollutants. Scientific Reports 9: 1-10.
Kim Y, Gu C, Kim HU, Lee SY (2020). Current status of pan-genome analysis for pathogenic bacteria. Current Opinion in Biotechnology 63: 54-62.

Librán-Pérez M, Pereiro P, Figueras A, Novoa B (2019). Antiviral activity of palmitic acid via autophagic flux inhibition in zebrafish (Danio rerio). Fish and Shellfish Immunology 95: 595-605.

Londo G (1984). The decimal scale for relevés of permanent quadrats. Sampling methods and taxon analysis in vegetation science: releve surveys, 'Vegetationsaufnahmen', floristic analysis of plant communities. No. 4, pp. 45-49. Junk.

Mendis E, Kim SK (2011). Present and future prospects of seaweeds in developing functional foods. Advances in Food and Nutrition Research 64: 1-15.

McFall-Ngai, M (2007). Care for the community. Nature 445: 153-153.

Mine I (2008). Biological Interactions during the life history of seaweed-A microscopic review. Kuroshio Science 2: 35-40.

Mofeed J, Sabry A, Deyab M (2019). Evaluation of Biochemical composition and bioactivities of two Ulva species (Ulva lactuca and Ulva fasciata): A comparative study. Bioscience Research 16: 3801-3811.

Morán-Santibañez K, Peña-Hernández MA, Cruz-Suárez LE, RicqueMarie D, Skouta R et al. (2018). Virucidal and synergistic activity of polyphenol-rich extracts of seaweeds against measles virus. Viruses 10: 465.

Moustafa M, Taha T, Elnouby M, Abu-Saied M, Shati A et al. (2018). Feasible design for electricity generation from Chlorella vulgaris using convenient photosynthetic conditions. Biocell 42: 7.

Nishide E, Uchida H, (2003). Effects of Ulva powder on the ingestion and excretion of cholesterol in rats. The 17th International Seaweed Symposium, pp. 165-168. Oxford Press.

Rezazadeh H, Buazar F, Matroodi, S (2020). Synergistic effects of combinatorial chitosan and polyphenol biomolecules on enhanced antibacterial activity of biofunctionalaized silver nanoparticles. Scientific Reports 10: 1-13.

Schwartsmann G, Brondani da Rocha A, Berlinck RG, Jimeno J (2001). Marine organisms as a source of new anticancer agents. Lancet Oncology 2: 221-225.

Shaheen M, Borsanyiova M, Mostafa S, Chawla-Sarkar M, Bopegamage S, El-Esnawy $\mathrm{N}$ (2015). In vitro effect of Dodonaea viscosa extracts on the replication of coxackievirus B3 (Nancy) and rotavirus (SA-11). Journal of Microbiology and Antimicrobial Agents 1: 47-54.

Shaheen M, Borsanyiova M, Mostafa S, Sarkar M, Bopegamage S (2017). In vitro and in vivo evaluation of Bauhinia variegata extracts to prevent coxsackievirus B3 infection. Journal of Proteomics \& Bioinformatics 10: 3 .

Shi Q, Wang A, Lu Z, Qin C, Hu J, Yin J (2017). Overview on the antiviral activities and mechanisms of marine polysaccharides from seaweeds. Carbohydrate Research 453: 1-9.

Shilova I, Semenov A, Kuvacheva N, Suslov N, Mustafin R (2012). Isolation, identification, and nootropic activity of compounds in Alfredia cernua chloroform extract. Pharmaceutical Chemistry Journal 46: 363-368.

Singh RK, Kukrety A, Sharma OP, Baranwal S, Atray N, Ray SS (2016). Study of a novel phenolic-ester as antioxidant additive in lube, biodiesel and blended diesel. Journal of Industrial Engineering Chemistry 37: 27-31.

Smit A (2004). Medicinal and pharmaceutical uses of seaweed natural products: A review. Journal of Applied Phycology 16: 245-262. 
Soares AR, Robaina M, Mendes GS, Silva TS, Gestinari L et al. (2012). Antiviral activity of extracts from Brazilian seaweeds against herpes simplex virus. Revista Brasileira de Farmacognosia 22: 714-723.

Taskin E, Ozturk M, Kurt O (2007). Antibacterial activities of some marine algae from the Aegean Sea (Turkey). African Journal of Biotechnology 6: 2746-2751.

Temiz C, Kalemci S, Micili SC, Tekmen I, Yildiz G et al. (2015). The effect of methyl palmitate on treatment of experimental asthma. Journal of Pakistan Medical Association 65: 632-636.

World Health Organization (2013). Rotavirus vaccines: WHO position paper-January 2013. Weekly Epidemiological Record=Relevé épidémiologique hebdomadaire $\mathbf{8 8}$ : 49-64.

Yeom JS, Park JS, Kim YS, Kim RB, Choi DS et al. (2019). Neonatal seizures and white matter injury: Role of rotavirus infection and probiotics. Brain Development 41: 19-28. 